\title{
Pharmacognostical and Pharmacological Review of Cucumis Melo L. Including Unani Medicine Perspective
}

\author{
Waseem $\mathbf{M}^{1}$, Rauf $\mathrm{A}^{2}$, Rehman $\mathrm{S}^{2 *}$ and Ahmed $\mathbf{R}^{2}$ \\ ${ }^{1}$ Department of Psychiatry, All India Institute of Medical Sciences, India \\ 2Department of Ilmul Advia (Unani Pharmacology and Pharmaceutical Science) Aligarh \\ Muslim University, India
}

Review Article

Volume 2 Issue 3

Received Date: June 06, 2018

Published Date: June 20, 2018

*Corresponding author: Sumbul Rehman, Department of Ilmul Advia (Unani Pharmacology and Pharmaceutical Science) Aligarh Muslim University, Aligarh, India, Email: dr.sumbulrehman@gmail.com

\begin{abstract}
Cucumis melo which is commonly known as musk melon or Kharbuzah belongs to the family Cucurbitaceae. It is an annual climbing or creeping herb with angular, scabrous stem, simple soft hairy orbicular-reniform leaves and bears tendrils, by which it is readily trained over trellises. Musk melons are extensively cultivated throughout India particularly in the hot and dry North-Western areas. Main parts used are pulp, root, seeds and seed oil. It is having diuretic, emmenagogue, and cooling, demulcent, properties. Fruit has been used for several centuries to treat kidney disorders such as kidney and bladder stones, painful and burning micturition, ulcers in the urinary tract, suppression of urine and to treat cough, hot inflammation of the liver, liver and bile obstruction, eczema, etc. The oil from seeds is said to be very nourishing and contains linoleic acid (60-70\%), lecithin, cephalin and cerebroside isolated from seed oil. The seeds of melon contain multiflorenol, isomultiflorenol, and 24-methylenecycloartenol. Its antimicrobial, antioxidant, antihyperlipidemic, anti-inflammatory, analgesic, diuretic, anthelmintic, nephroprotective and cytotoxic activity, Analgesic and Anti-inflammatory Activity, Anti-oxidant and free radical scavenging activity, Anti-Vitiligo Effect, Anti-ulcer activity, Anti-cancer activity, Hepato-protective activity, Diuretic effect, Protects against Hypothyroidism, Anti-diabetic activity, Haemagglutination and Haemolysis, Antibacterial and Anthelmintic activity, Antimicrobial activity, Antifungal, Nematicidal have been proved by research studies.
\end{abstract}

Keywords: Tukhm-e-Kharpaza; Cucurbitaceae; Diuretic

Abbreviations: TPC: Total Phenolic Compounds; BAL: British Anti-lewisite; EDTA: Ethylene Diamine Tetra Acetic Acid; SOD: Superoxide Dismutase.

\section{Introduction}

Cucumis melo Linn. is a well-known plant of Cucurbitaceae indigenous and largely cultivated in India, 
particularly in hot, dry, North-Western areas, Northern Bengal, Kashmir and Afghanistan [1-3]. There are 40 species of herbs under this genus; seven species are native to India. It is a perennial trailling herb and distributed throughout India [4]. Plants are soft and hairy, leaves are round-ovate, obtuse, lobed or divided, angled and tendrils are simple. The plants of cucurbitaceous family are monoecious or with both male and female flowers. Flowers are yellow, $2.5 \mathrm{~cm}$ in diameter. Fruits are globose to oblong or slender and curved or coiled, pubescent and flavoured with musky scent [5].

\section{Taxonomical Classification}

Kingdom: Plantae

Class: Magnoliopsida

Order: Cucurbitales

Family: Cucurbitaceae

Genus: Cucumis

Species: Cucumis melo Linn.

\section{Vernaculars}

Arabic- Battikh, Bengali- Kharmuj; Bombay- Kharabuja, Chibuda, Kakadi, Kharbuja, Kharbuj; Cannada- Kalingada; Chinese- Kankua, Then kwa, Hiang-kwa,Tien Kua; English-Sweet melon, Musk melon, Melon; FrenchCantaloup, Melon; German- Melonegurke, Melone; Gujarati- Turbuch, Kharbuja, Teti, Chibdu, Shakarateli, Tarbucha; Hindi-Khurbuza, Sakkarteli, Kharbuja, Kachra,Patkira, Phut,Tuti, Kharbuza, Kakni, Kakri; LatinCucumis melo; Madras- Mulam; Marathi- Kharbuja, Khurbuj, Valuk, Chibunda, Kharbuja; Persian- Kharbuzeh, Kharpaza; Punjabi- Kharbuja,Gilas, Girasa; RussianMelon; Sanskrit- Kalinga, Kharvuja, Kharbuja, Madhupaka, Amritavha, Dashangula, Karkati, Madhupaka, Madhuphala, Phalaraja, Shadbhuja, Shadrekha, Tikta, Tiktaphala, Vrittakarkatti, Vrittervaru; Sindhi- Gidhro; TamilVealapalam,Vellari-verai, Mulampazham, Mulam; TeluguVelipanda, Kharbuzadosa, Putzakova, Velipandu, Mulam; Unani- Khafis; Urdu- Kharbuzah [2,3,6-14].

\section{Morphology}

Cucumis melo Linn. is an annual herb with stems creeping, angular, scabrous, leaves about $7.5 \mathrm{~cm}$ in diameter, orbicular-reniform in outline, 5-angled or lobed, scabrous on both surfaces and also often with soft hairs, lobes neither deep nor acute, petiole $5 \mathrm{~cm}$, petals are 1.6 $\mathrm{cm}$ long. Female peduncles are sometimes $5 \mathrm{~cm}[10]$. Flowers yellow, monoecious, males clustered in the axila, female solitary, all shortly peduncled. Male: calyx-tube top-shaped or campanulate, 5lobes, 3 stamens; free anthers, one 1-celled, or two 2-celled, cells conduplicate or much flexuose, connective produced in a crest. Female: Calyx and corolla as in the male flower; ovary ovoid, style short, with three obtuse stigmas, many ovules, horizontal, 3 placentas [15]. Fruit is spherical, ovoid, elongated or contorted, glabrous or hairy, not spinous nor tuberculate [10].

\section{Macroscopic}

Fruits $15 \times 10 \mathrm{~cm}$ White, Flat, Oblong, longitudinal stripe, Apex and Base blunt narrow at the tip [1]. The seeds are oval-oblong, cream coloured, about $10 \mathrm{~mm}$ long and $2 \mathrm{~mm}$ wide, laterally flattened having a smooth outer surface. Seeds one end broader but tapering at the other exalbuminous with prominent cotyledons. Seeds have sweet taste but no odour and ten seeds weigh about 0.29 gram in average [16].

\section{Microscopic}

Cross section of seed shows the outer test which is bounded externally by epidermis, made up of characteristic palisade cells but with pointed unbranched ribs, often only the ribs are present. Immediately within the epidermis are several layers of pitted stone cell. This region is terminated internally by single layer relatively thin walled lignified pitted cells. The rest of the testa consists of spongy cells. Perisperm consists of 3 or 4 layers of small cells, the other most layer of which is of regular cells having thickened fatty walls. Endosperm is in form of single layer of thin walled cells having oil drops and aleurone grains. Embryo is also parenchymatous and cell rich in oil drops and aleurone grains [16].

\section{Geographical Distribution}

It is found throughout the world [16], but popular as native of Africa, extensively cultivated in India, chiefly in hot, dry, North-Western areas [1], particularly in Uttar Pradesh and Punjab [17].

\section{Description According to Unani Literature}

It is creeper having rough surface, leaves are round in shape, flowes are of different shapes and colours, plant commonly found in India and Pakistan [18]. Galen mentioned Cucumis melo as Qissa Nazeej (Pukhta kakdi/Mature cucumber). Descorides mentioned Cucumis melo with the name of flush and said that it is found in different shape, colour and size depending upon the geographical locations. He further described its various name for example- Bukharai, Samarqandi and Darabi. He mentioned that Garmak and bapaza are its best and medium varieties respectively [13]. 


\section{Parts Used}

Seed [12]; Fruit [13].

\section{Temperament (Mizaj)}

Hot $\left(1^{\circ}\right)$ and Wet $\left(2^{\circ}\right)[7,11,13,14,18-21]$, Hot $\left(2^{\circ}\right)$ and Wet (10) [22,14], Hot $\left(1^{\circ}\right)$ and Wet $\left(1^{\circ}\right)$ [14], Hot $\left(2^{\circ}\right)$ and Wet $\left(2^{\circ}\right)[13]$, Cold $\left(2^{\circ}\right)$ and Wet $\left(2^{\circ}\right)[8,23]$.

\section{Doses}

2-6 gram [19], 6.79-16.99 gms [21], 5-7 gram [7], 8.73 gm [14,22], 7-17gm [13].

\section{Adverse Effect}

Spleen [13-15,19,20], Cold temperament [13,19,21], Excessive use may cause Cholera [13,24].

\section{Correctives}

Honey $[13,19,20,25]$, Honey and Banafsha $[14,19,22]$, (Viola odorata) Zarishk (Berbaris Vulgaris) [13,21], Shahad (Honey), Banafsha (Viola odorata) [21], Saunf (Foeniculum vulgare) Sikanjabeen and Honey [14], Filfil siyah (Piper nigrum) [26].

\section{Substitute}

Tukhm-e-Khayarein (Cucumis sativa) [19,21], Badam Shireen (Prunus amygdalus), Chilgoza(Pinus geradiana) [1419,21,22].

\section{Pharmacological Action (Afa'al)}

Lithotriptic (Mufattit-e-Hasat) [18,26], Demulcent (Mulattif) [9,10], Diuretic ( Mudirr-e-Baul) [13,8,10,11,14,17,18,20,22,24,26], Emmenagogue (Mudirr-eHaiz) [14,18,22,26], Purgative (Mushil) [3], Cooling (Mubarrid) [1,2,9,10,17], Ralaxent (Murkhi) [2], Tonic (Muqawwi) [3,4,10], Laxative (Mulaiyyin) [10,19], Nutritive value (Mughazzi) [1,4,6,9,10,14,17,18], Aphrodisiac (Muqawwi-e-Bah) [10,27-29], Lactagogue (Muwallid-eLaban) [19,11,13,14], Cardio tonic (Muqawwi Qalb) [10], Nervine tonic (Muqawwi Asaab) [10], Astringent (Qabiz) [10], Liver deobstruent ( Mufatteh sudad-e-jigar) [8,13,14,18,21,22,26], Anti ulcer (Nafe Quruh) [20], Stomachic (Muqawwi-e-Meda) [4], Sedative (Musakkin) [4], Emetic (Muqi) [3,8,25,14], Detergent (Jali) [13,18], Quenching Thirst (Musakkin-e-Atsh) [24].

\section{Medicinal Uses (Mahalle Istemal)}

Acute and Chronic Eczema (Haad wa Muzmin Naar-eFarsi) [10,1,3], Freckles (Namash) [8,14], Dyspepsia (Zoaf$e$-Hazm) [10], Epilepsy ( Sar'a) [3], Prickly Heat (Hasf) [8], Burning micturition

(Hirqat-ul-Baul)
$[5,8,10,13,14,21,22,26]$, Urinary infection (Tadiya Majariy$e$-Baul) [3], Kidney and Bladder stone (Sang Gurda wa Masana) [8,13,26], Anuria (Ehtebas-e-Baul) [8,10,17,26], Amenorrhoea (Ehtebas-e-Haiz) [8,26], Ophthalmia (Iltihabe-Ain) [10], Bronchitis (Iltihab-e-Sho'abtur Riya) [10,29], Sore throat (Khashunat-e-Halaq) [8,13,21], Hepatitis (Warm-e-Jigar) [8,10,18,19,21,28], Fever (Humma) $[9,10,13,18,19,23,29]$, Cough (Su'al) [8,13,19], Thirst (Atash) [10,23], Insanity (Junoon) [10], Ascites (Istisqa) $[10,13,14]$, Allays fatigue (Thakan) [10], Headache (Sud'a) $[3,10]$, Chest pain (Waja-al-Sadr) $[8,19,21]$, Cirrhosis of the liver (Talaiyyuf-e-Kabid) [28], Gonorrhoea ( Sozak) [9,18,21], General debility (Zoaf-e-Umoomi) [9], Cholasma (Jhaiyan) [14,19], Jaundice (Yarqan) [11,13,14,18,28], Constipation (Qabz) [3,11,19], Indigestion (Sue Hazm) [3], Renal stone (Hasat-e-Kuliya) [14], Ulcers (Quruh) [29], Dermatitis (Iltehab-e-Jild) [29], Strangury (Taqteer-ul-Baul) $[10,18]$.

\section{Important Formulation}

Banadiq-e-buzoor, Sharbat-e-buzoori [18,26], Qurs-eSartan kafoori, Majoon-e-Kaknaj[30], Qurs-e-Kafoor, Qurs-eSartan, Sharbat-e-Mudir, Lubub-e-barid, Majoon-e-Hajrul Yahood [31].

\section{Phytochemistry}

Protein content of seed meal $49.93 \%$ amino acid composition also determined [32]. Fixed oil, starch, resin and sugar [9]. Sulphur compounds (mostly thioesters) are responsible for the characteristic aroma of the fruit. 3Methylpropanenitrile originating from 2-methyl-thioethyl glucosinolate through the action of myrosinasethioence of myrosinase activity in fruit because of 3-methyl propanenitrile.This activity seems to increase with the maturation of the fruit [29]. The melon contains elaterin or melotoxin and cucurbitacins B and E. The seeds contain melonin and some trypsin-inhibitors, CMeTI-A and CMeTIB. Recently, a special protein, cucumisin, has been isolated from the juice of the melon fruit [28]. Total kernel lipids contained neutral lipids (91.5), glycolipids (6.4) and phospholipids (2.1\%).Neutral lipids consisted mostly of triacylglycerols (90.7\%). Monoand diagalactosyldiacylglycerol identified as major glycolipids, and phosphatidylcholine and phosphatidylglycerolamine as major phospholipids [33]. The research on C. Melo suggested that the regulation of sugarmetabolism differs between oriental melons and other types of melons. The KEGG pathwayresults and DEG analysis in the study suggest that genes involved in the glucose and fructosemetabolic pathways were up-regulated early during fruit development (8 DAP), which isconsistent with the previous results. The genes involved in sucrose 
synthesis were activatedearly in fruit development and subsequently down-regulated from 16 DAP to 32 DAP [34]. The main fatty acids identified so far were linoleic, oleic, palmitic and stearic acids with respective contents $60.1 \%$, $25.3 \%, 10.1 \%$ and $4.5 \%$. Mineral analysis revealed significant levels of potassium, magnesium, calcium and sodium, namely 509.80, 101.71, 55.39 and $41.17 \mathrm{mg} / 100 \mathrm{~g}$ respectively [35]. Terpenoid profile of C. melo Linn. was elucidated using high performance thin layer chromatography (HPTLC). The $\mathrm{R}_{\mathrm{f}}$ value of the different compounds present in the extract was found to be 0.06 , 0.21 and 0.93 of peak 1, 2 and 3 respectively. Among them, peak 1 was found to be terpenoid compounds. C. melo fruit extract showed the presence of terpenoids and it was confirmed from the chromatogram after derivatization [36]. The effect of freeze-drying on the antioxidant compounds and antioxidant activity tests showed that there were no significant $(p<0.05)$ differences found between the fresh and freeze-dried fruit of muskmelon in the amounts of total phenolic compounds (TPC) and change observed in the ascorbic acid content [37].

The methanolic extract of the seeds of $C$. melo L. var. reticulatus afford three new chromone derivatives; 5, 7dihydroxy-2-[2-(4-hydroxyphenyl)ethyl] chromone, 5, 7dihydroxy-2-[2-(3,4-dihydroxyphenyl)ethyl] chromone and 7-glucosyloxy-5hydroxy-2-[2-(4-hydroxyphenyl)ethyl] chromone, together with three known compounds; betaamyrin, beta-sitosterol and beta-sitosterol-3-0-betaglucopyranoside [38].

A new phenolic glycoside (E)-4-hydroxycinnamyl alcohol 4-0-(2'-O- $\beta$-D-apiofuranosyl) ( $\left.\quad 1^{\prime \prime} \rightarrow 2^{\prime}\right)-\beta$-Dglucopyranoside was isolated and identified from Cucumis melo seeds together with benzylO- $\beta$-D-glucopyranoside, 3 , 29-0-dibenzoylmultiflor-8-en-3 $\alpha, 7 \beta, 29$-triol and 3-0pamino-benzoyl-29-0-benzoylmultiflor-8-en-3 $\alpha, \quad 7 \beta, \quad 29$ triol [39].

21 cucurbitane-type triterpenoids, including 9 new compounds and 12 known compounds were isolated and identified from the stems of Cucumis melo. 2 known compounds, cucurbitacin-B and cucurbitacin-A showed significant cytotoxic activity against the proliferation of A549/ATCC and BEL7402 cells in vitro. Out of 9 new compounds, only compound 7 were weakly cytotoxic [40].

\section{Pharmacological Studies}

\section{Analgesic and Anti-inflammatory Activities}

The methanolic extract of $C$. melo seeds possesses potent analgesic property. Carrrageenin indues accumulation of leukocytes in the pleural cavity, as well as the enhancement of $\mathrm{LTB}_{4}$ levels in pleural exudates after inflammatory stimulus. Migration of neutrophils to the affected area constitutes an important pro-inflammatory factor, as they liberate toxic oxygen radicals in the extracellular medium. C. melo inhibited the leukocyte influx and diminished $\mathrm{LTB}_{4}$ levels, thereby producing antiinflammatory effect [41].

\section{Anti-0xidant And Free Radical Scavenging \\ Activity}

The methanolic extract of cantaloupe has shown DPPH and hydroxyl radicals scavenging activity. This activity of cantaloupe extracts is particularly due to the presence of phenolic compounds especially flavonoids. High antioxidant activity was observed in the leafand stem extracts of cantaloupe [42]. The methanolic extract of the seeds has the highest DPPH radical scavenging activity than methanol extracts of leaf, stem, skin and flesh of the melon. The high antioxidant activity of the waterand methanol-water extract may be due to the high amounts of caffeic acid present in these extracts [43]. Differential CmADHs expression suggested tight adaptation of the fruit to the developmental events [44].

\section{Anti-Vitiligo Effect}

An open observational study to evaluate the efficacy and safety of the investigated product containing phenylalanine, $C$. melo extract and acetyl cysteine, given alone or in combination with 311-nm narrow band microphototherapy, excellent repigmentation $(>75 \%)$ was achieved by $38-73 \%$ of patients, depending on the treatment regimen. Mild to moderate side effects were observed only in patients treated with clobetasol $0.05 \%$ ointment. The tested gel formulation showed a good efficacy in improving vitiligo repigmentation. No side effects were observed [45].

\section{Anti-Ulcer Activity}

The methanolic extract of $C$. melo seeds exhibited antiulcerogenic activity. The mechanism of its gastroprotective activity may be attributed to reduction in vascular permeability, scavenging of free radicals and diminished lipid peroxidation along with strengthening of mucosal barrier. Presence of phytoconstituents, triterpenoids and sterols are responsible for these actions [41].

\section{Anti-Cancer Activity}

Cucurbitacins are extremely oxygenated tetracycliictriterpenes, primarily establish in the cucurbitaceae 
family. Cucurbitacin B is an anticancer (oncogenic) agent naturally isolated from the stems of $C$. melo. In human leukemia cells, the anti-cancer activity of cucurbitacin B has been reported. Cucurbitacin B inhibit Raf/MEK/ERK and STAT 3 activation pathway in leukemia cell line K562. Cucurbitacin A along with cucurbitacinE also own major anti-tumour activity [40]. Significant reductionin odd ratio (95\%) was seen with consumption of melon [3].

\section{Hepato-Protective Activity}

The dried pedicel of $C$. melo $\mathrm{L}$. has been observed to improve hepatic functionand to increase gluconeogenesis.It has a protective effect against $\mathrm{CCl}_{4}$ intoxication.It is used to treat toxic and chronic hepatitis, jaundice and cirrhosis of liver [46].

\section{Diuretic Effect}

The ether extract of seeds $(0.5 \mathrm{ml} / \mathrm{kg}$ bw, i.v. $)$ in dogs caused diuresis by increasing the glomerular filtration rate and also by interfering with the reabsorption of chloride and possibly sodium ions in the tubules. Further, the diuretic as well as chloruretic activity of the extract was antagonised by the compounds like BAL (British antilewisite), and EDTA (Ethylene diamine tetra acetic acid). The mechanism of the action may be similar to mercurial [3]. C. melo at a dose $400 \mathrm{mg} / \mathrm{kg}$ showed an extremely significant $(p<0.0001)$ diuretic effect compared to the positive control Furosemide. C. melo possessed more diuretic activity when compared to the standard (Furosemide) [47].

Gentamicin treated group showed increased levels of blood urea nitrogen and serum creatinine, which were significantly retrieved in group pretreated with methanolic extract of C. melo (ME-CM) seed kernel. The level of superoxide dismutase, catalase, glutathione peroxidase and reduced glutathione were increased with decrease in malondialdehyde content in ME-CM pretreated group when compared with gentamicin alone treated group. The histopathological analysis also showed the protective nature of ME-CM in gentamicin-induced renal damage [48].

\section{Protects Against Hypothyroidism}

Administration of 3 test fruit peel extracts (M. indica, C. vulgaris and C. melo) significantly increased both the thyroid hormones (T3 andT4) with a concomitant decrease in tissue lipid peroxidation, suggesting their thyroid stimulatory and antiperoxidative role.This thyroid stimulatory nature was also exhibited in propylthiouracil induced hypothyroid animals [49].

\section{Anti-Diabetic Activity}

The ethanolic extract of plant in a dose of $250 \mathrm{mg} / \mathrm{kg}$ p.o. did not lower the blood sugar level in streptozotocininduced diabetic male albino rats [3]. Although the fruit peel extracts of C. melo reversed the CCT-diet (supplemented with $4 \%$ cholestrol, $1 \%$ cholic acid and $0.5 \%$ 2-thiouracil) induced increase in the levels of tissue lipid peroxidation, serum lipids, glucose, creatinine kinaseMB. Furthermore, Musk melon increased the levels of thyroid hormones and insulin indicating their potential to ameliorate the diet induced alterations in serum lipids, thyroiddysfunctions and hyperglycemia/diabetes mellitus. These beneficial effects could be due to the rich content of polyphenols and ascorbic acid in the peel extracts [49]. Oxykine is the cantaloupe melon extract rich in vegetal superoxide dismutase (SOD) covered by polymeric films of wheat matrix gliadin.The treatment of oxykine ameliorated the progression and acceleration of diabetic nephropathy in type-2 diabetic rodents. The oxykine reduced the diabetes induced oxidative stress and renal mesangial cell injury. Oxykine might be a novel approach for the prevention of diabetes nephropathy [50].

\section{Haemagglutination and Haemolysis}

The lectins from the seeds, when tested for haemagglutinating activity with erythrocytes of human, rabbit, cow, sheep, guinea pig, dog, monkey, chicken, horse, goat and pig haemolysed the red cells of rabbit, dog and monkey only [3].

\section{Antibacterial and Anthelmintic Activity}

The seeds growing on cattle dung heaps showed inhibition of the spores of B. subtilis, E. coli, P. cichorii and $S$. Typhi (Anonymous, 2009). The $\mathrm{n}$-hexane and methanolic extracts of the seeds of C. melo L. have shown good antimicrobial and anthelmintic activity [38].

\section{Antimicrobial Activity}

The aqueous, heptane, petroleum ether and acetone extract of the whole plant of C. melo Linn, P. daemia Frosk. (Asclepiadaceae) was screened for the antibacterial and antifungal activity by highest Zone of Inhibition was shown by whole plant and fruit extract of C. melo Linnwith aqueous and acetone with C. albicans and E. coli 08 and 12 $\mathrm{mm}$ respectively. Very poor response was observed with acetone and aqueous extract in other bacterial and fungal stains. Highest zone of inhibition was shown by whole extract of Pergularia daemia with heptane with E. coli and C. albicans, 16 and $21 \mathrm{~mm}$ respectively [51]. 


\section{Antifungal Activity}

The aqueous and ethanolic extract of the fruits were found to be devoid of antifungal activity against $A$. nigerand T. rubrum. The oil cake inhibited mycelial growth of Rhizoctoniasolani causing stem rot of chilli [3].

\section{Nematicidal Activity}

The seed extract showed concentration dependent mortality of Meloidogyneincognite and R. Reniformis [3].

\section{Anti-Angiogenic Activity}

In this study, the purified trypsin inhibitor from Cucumismelo seeds using a procedure and the effectiveness of its anti-angiogenic activity on three dimensional cultures of HUVECs was determined. C. melo seeds are rich in urease, lipase, lipoxygenase and trypsin inhibitor which is considered for their enzyme inhibitor activities.Treatment with TICMS at six doses resulted in a significant decrease of endothelial cell proliferation with an $\mathrm{IC}_{50}$ value of about $20 \mu \mathrm{g} / \mathrm{ml}[52]$.

\section{Nutritive Value}

The study revealed that melon (C. melo L. Inodorus) seeds are an important source of minerals, namely $\mathrm{K}, \mathrm{Ca}$ and Mg. Magnesium is showing increasing interest for the adequate heart function; its presence would be taken advantage of for people with limited resources. Moreover this oil showed interesting amounts of unsaturated fatty acids as compared to other known edible oils. As nutritionists generally recommend a Mediterranean diet especially for cardiovascular concerns, melon seeds oil could be taken advantage of for its content of both linoleic and oleic acids palmitic and stearic acids with respective contents $60.1 \%, 25.3 \%, \quad 10.1 \%$ and $4.5 \%$.are food supplements to improve health conditions [35].

\section{References}

1. Dolidas, Agarwal VS (1991) Fruit Drugs Plants of India. $1^{\text {st }}(E d n)$, Kalyani Publishers, New Delhi-Ludhiana, pp: 72.

2. Dey KL (1973) The Indigenous Drugs of India. $2^{\text {nd }}$ (Edn.) Pama Primlane, The Chronica Botanica, New Delhi, pp: 103-104.

3. (2009) Indian Medicinal Plants. Indian Council of Medical Research. New Delhi, 8: 210-221.

4. Bhattacharjee SK (2004) Handbook of Aromatic Plants. Pointer publishers, Jaipur, India, pp: 150.
5. Bhattacharjee SK, De LC (2005) Medicinal Herbs and Flowers. Aavishkar Publishers, Distributors Jaipur, India, pp: 114.

6. Nadkarni KM (1954) Indian Materia Medica. $3^{\text {rd }}$ (Edn.), Popular Book Depot, Bombay, Dhootapapeshwar Prakashan Ltd. Panvel, Volume I, pp: 402-403.

7. Daljeet (1974) Unani Dravyagun Darsh. Ayurvedic and Tibbi Academy, Uttar Pradesh, Volume II, pp: 294-295.

8. Al-Baitar I (1985) Al-Jameul Mufridat al Adviawa AlAghzia. (UrduTranslation), CCRUM, New Delhi, Volume I, pp: 248-252.

9. Khory HK, Katrak NN (1985) Materia Medica of India and Therapeutics. $3^{\text {rd }}$ (Edn.) Neeraj Publishing House Delhi, pp: 309-310.

10. Kirtikar KR, Basu BD (1987) Indian Medicinal Plants. $2^{\text {nd }}$ Edi. International Book Distributors, Dehradun. Volume II, pp: 1140-1142.

11. Dayal KS (1993) Vedic Nighantoo or Vedic Makhzanul Mufridat. Kutub Khana Anjuman, Taraqqi Urdu Bazar Delhi, pp: 79.

12. Naik VN (2004) Identification of Common Indian Medicinal Plants. Scientific Publishers, Jodhpur India, pp: 131.

13. Azam Khan (2013) Muheet-e-Azam. (Urdu translation) CCRUM, New Delhi, Volume II, pp: 430-435.

14. Alam M (YNM) Makhzanul Mufridat ma Tashreehul Advia. Publisher wa tajirane Kutub, Bulroad Kashmir bazaar, Pakistan, pp: 117.

15. Hooker JD (1982) The Flora of British India. M/S Bishen Singh Mahendra Pal Singh, New Connaught Place, Dehradun, Volume II, pp: 619-620.

16. (2006) Qarabadeen-e-Sarkari. CCRUM, New Delhi, Volume II, pp: 63.

17. Chopra RN, Chopra IC, Handa KL, Kapur LD (2006) Indigenous Drugs of India. $3^{\text {rd }}$ (Edn), Academic Publishers, Kolkata, pp: 502.

18. Lubhaya HR (1977) Goswami Bayanul Advia. Goswami pharmacy, Delhi, Volume I, pp: 224-226.

19. Ghani MN (1911) Khawasul Advi. Steam Press Lahore, Volume I, pp: 497. 
20. Haleem HMA (2009) Mufradat-e-Azizi. CCRUM, New Delhi, pp: 69.

21. Ghani N (2010) KhazainulAdvia. CCRUM, New Delhi, Volume IV, pp: 59-60.

22. Nabi MG (2007) Makhzanul Mufridat wa Murakkabat Maroof ba Khawasul Advia. Part-3, CCRUM, New Delhi, pp: 122.

23. Harvi MY (1894) Behrul Jawahar. Mujtaba Press, Delhi, pp: 59.

24. Razi AMZ (1991) Kitab-al-Mansoori. (Urdu translation), CCRUM, New Delhi, pp: 121.

25. Hakeem HA (2002) Bustanul Mufridat Jadeed. Idara Kitab-ush-Shifa, Darya Ganj, New Delhi, pp: 260-262.

26. Usmani MI (2008) Tanqeehul Mufridat. Ibn Sina Tibbiya College, Azamgarh, pp: 120.

27. Ibn Rushd AWM (1987) Kitabul Kulliyat. (Urdu Translation), CCRUM, New Delhi, pp: 255.

28. Huang KC (1999) The Pharmacology of Chinese Herbs.

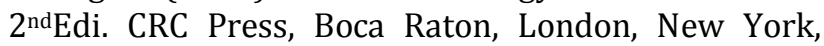
Washington DC, pp: 245-246.

29. (2001) The Wealth of India - A Dictionary of Indian Raw Materials andIndustrial Product. National Institute of Science Communication, Council of Scientific \& Industrial Research New Delhi, Volume II: Cl-Cy. pp: 252-253.

30. (2006) Standardization of Single Drugs of Unani Medicine. Central Council for Research in Unani Medicine, New Delhi, Volume III, pp: 105-109.

31. Kabiruddin (2000) Makhzanul Mufridat al Maaruf Ba Khwasul advia. Faisal Publications, Deoband, pp: 265266.

32. Rastogi RP, Mehrotra BN (2001) Compendium of Indian Medicinal Plants. Central Drug Research Institute, Lucknow and National Institute of Science Communication, New Delhi, Volume III, pp: 215.

33. Rastogi RP, Mehrotra BN (1999) Compendium of Indian Medicinal Plants. Central Drug Research Institute, Lucknow and National Institute of Science Communication, New Delhi, Volume V, pp: 262.

34. Shin AY, Kim YM, Koo N, Lee SM, Nahm S, et al. (2017) Transcriptome analysis of the oriental melon (Cucumis melo L.var makuwa) during fruit development. Peer journal. Volume 5.

35. Bouazzaoui N, Drici W, Bouazzaoui W, Arrar Z, Bendiabdellah Mulengi JK (2016) Fatty acids and minerals composition of Melon (cucumis melo $\mathrm{L}$. Inodorus) seeds from West Algeria, Mediterranean journal of Chemistry 5(1): 340-346.

36. Vidya R, Kalaivani K, Venkatesh R (2014) Phytochemical Standardization of Cucumis melo L. Extract by HPTLC Techniques. Am J Pharm Tech Res 4(4): 344-350.

37. Shofian NM, Hamid AA, Osman A, Saari N, Anwar F (2011) Effect of freeze-drying on the antioxidant compounds and antioxidant activity of selected tropical fruits. Int J Mol Sci 12(7): 4678-4692.

38. Ibrahim SR (2010) New 2-(2-phenylethyl) chromone derivatives from the seeds of cucumis melo L.var.reticulatus. Natural product communications 5(3): 403-406.

39. De Marinoa S, Festaa C, Zolloa F, Iorizzi M (2009) Phenolic glycosides from Cucumismelo var. inodorus seeds. Phytochemistry Letters 2(3): 130-133.

40. Chen C, Qiang S, Lou L, Zhao W (2009) Cucurbitanetype tri-terpenoids from the stems of Cucumis melo. J Nat Prod 72(5): 824-829.

41. Gill NS, Bajwa J, Sharma P, Dhiman K, Sood S, et al. (2011) Evaluation of antioxidant activity of traditionally consumed cucumis melo seeds, Journal of pharmacology and toxicology 6(1): 82-89.

42. Ismail HI, Chan KW, Mariod AA, Ismail M (2010) Phenolic content and Antioxidant activity of cantaloupe (C.melo) methanolic extracts, Food chemistry 119(2): 643-647.

43. Zeb A (2016) Phenolic Profile and Antioxident Activity of Melon (Cucumismelo L.) seeds from Pakistan. Foods 5(4): 67.

44. Jin B, Zhang C, Liu W, Tang Y, Qi H, et al. (2016) The Alcohol dehydrogenase Gene Family in Melon (C.meloL.): Bioinformatic Analysis and Expression Pattserns, Frontiers in Plant science 7: 670.

45. Buggiani G, Tsampau D, Hercogova J, Rossi R, Brazzini B, et al. (2012) Clinical efficacy of a novel topical formulation for vitiligo: compared evaluation 
ofdifferent treatment modalities in 149 patients, Dermatol Ther 25(5): 472-476.

46. Wang J, Zhou X, Cao Y, Xiao J, Ma E, et al. (2007) The anti tumor activities of Cucurbitacin Liposome for injection both in vitro and in vivo. Asian Journal of traditional medicines 2(3): 98-103.

47. Ravishankar K, Vishnupriya PSV (2012) Evaluation of diuretic effect of ethanolic seed extracts of macrotylomauni florum and cucumis melo in rats. International journal of pharma and Bio Sciences 3(3): 251-255.

48. Fahamiya N, Aslam M, Siddiqui A, Shiffa M, Ahmed A, et al. (2012) Pharmacognostical study and Development of Quality control Parameters for Cucumismelo Linn. American J of Pharmtech Research.

49. Parmar HS, Kar A (2009) A Protective role of Mangifera indica, Cucumis melo and Citrullus vulgaris peel extracts in chemically induced hypothyroidism. Chem Bio Interact 177(3): 254-258.

50. Naito Y, Akagiri S, Uchiyama K, Kokura S, Yoshida N, et al. (2005) Reduction of diabetes-induced renal oxidative stress by a cantaloupe melon extract/gliadinbbiopolymersoxykine, in mice. Biofactors 23(2): 85-95.

51. Hemant AT (2015) Antimicrobial and antifungal activity of Cucumis melo linn. (Cucurbitaceae) and Pergulariadaemia frosk (ascalpiadaceae) an ethnomedicinal plants. International Journal of Bioassays 4(1): 3661-3665.

52. Rasouli H, Parvaneh S, Mahnam A, Rastegari-Pouyani M, Hoseinkhani Z, et al. (2017) Anti-angiogenic potential of trypsin inhibitor purified from cucumis melo seeds: Homology modelling and molecular docking perspective, International journal of Biological macromolecules 96: 118-128.

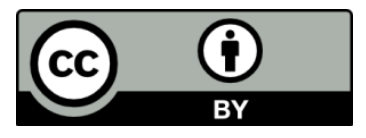

